\title{
The Investigation and Assessment on Current Situation of Concentration Ratio on China Audit Market
}

\author{
Mo-Fan QIN ${ }^{1, a}$ \\ ${ }^{1}$ College of liberal arts, The University of Minnesota, Minneapolis 55414, Minnesota USA \\ aqinxx261@umn.edu
}

Keywords: Audit Market, Market Concentration Ratio, Audit Quality.

\begin{abstract}
In recent years, with the fast developing of capital market, requirement on audit quality of listed company is China is getting stricter and stricter. It has been a focus of all fields about how to optimize the audit market structure to adapt the demand of benign development of audit market. This article has selected the relevant information of the listed companies in Shanghai and Shenzhen during 2015 to 2017, to investigate and analyze the China audit market concentration ratio from the view of improving audit quality and came up with relevant political advises based on this.
\end{abstract}

\section{Come up with questions}

The development of audit industry in the U.S is representing the operational situation of international CPA industry. During the development process in hundreds of years, the audit market concentration ratio kept increasing, the market feature of monopoly or oligopoly also appeared and got more and more salient, so the audit quality was reduced. Against to this idea that, the audit market concentration ratio of our nation is quite low, so very hard to form up the scale economy, thus the audit quality is not satisfied. According to this, the Chinese government came up with the market development strategy against to the U.S, the relevant industrial associations cooperated with government and issued some related policies --- from June of 2000 to September of 2006, the China Association of CPA issued some policies including "the idea about to strengthen accounting firm and enlarge the scale”, which comprehensively planned the relevant measures to promote the expanding on accounting firms of our nation. By issuing the above policies, it's very clear that the government is expecting to support the enlargement of CPA firms in our nation by administrative power. However, after decades of development, what's the degree of the market structure and competition type of the China audit market at present? Has the development of audit market achieved expectation? With the aim of optimizing audit market structure and improving audit quality, the article thinks it is very necessary to process the investigation and assessment of the China audit market concentration ratio of the current situation. According to this, this article processed investigation and assessment of the China audit market concentration ratio and the competition type in the view of client assets and client quantity by CRn index. In this way the government can take this as the reference for formulating relevant industrial policies and improve the audit quality and enhance audit efficiency of the audit industry in our nation.

\section{Literature review}

Zef and Fossum [1] had a pioneering research on the structure and type of audit market. They firstly used client assets, client incoming and profit amount and other indexes to measure all firms of their specific industries by the market share in audit business. The analysis conclusion thought, the top 8 auditing firms shared most part of the market shares, however in different industries, each firm has huge differences on the major ratio. Then, Schiff and Fried[2] calculated the firms which ranked by the top of 1972 and 1973 in "Fortune Magazine" ranking list and processed the analysis. After comparing with Zef's conclusion, it's realized that the U.S audit market had experienced 5 years' development, and the market structure was not obviously changed. These initial researches 
established the base for assessing concentration ratio of audit market. However, due to the limitation of the collected data, the samples covered a little ranges. Came after this, some scholars extended the researching range based on predecessors' researching achievement. Eichenseher and Danos [3] discussed all elements and logistical relations which leaded to the changes on concentration ratio in some specific industries. The experiential evidence of this article stated that: there were two elements influencing the concentration ratio of audit market, as 1: if the audited client was in the regulated professions, 2: the important of issuing new shares in specific industries. Meanwhile, the concentration ratio of audit market in specific industries would also be influenced by the personal concentration ratio of the auditing industry itself.

As for the relation between concentration ratio of audit market and auditing quality, Dye [4], DeAngelo [5] thought the high concentration ratio could ensure that the auditing firm with better independence, thus the high auditing quality could be guaranteed. Jong- HagChoi [6] and others chose the accrued profits of the abnormal values to assess the audit quality during the process of analyzing the influence from auditing scale to auditing charges, auditing quality. Meanwhile, auditing charges amount and the audited clients quantity of these two indexes was applied to assess the scale of auditing firm. Finally it was approved that, compared to small-scaled firms, the large-scaled firms provided a better quality on auditing service, which would also be appeared in auditing charges of the firms. Ding [7] studied and analyzed a merger case between PWC and Cooper in the UK, proofed from the view of client's earning quality that, after the merger the auditing quality was highly improved. Besides, the auditing charges amount was also improved on a certain level.

\section{Current Situation Analysis of Concentration Ratio on China Audit Market --- based on CRn index}

\section{The Assessment and Selection on Indexes for Measuring the Concentration Ratio}

When selecting measuring indexes, the following three elements shall be concerned: (1) the selected measuring index can be compared auditing market and horizontally. (2) the selected index shall be easy to obtain and exact. (3) the selected index shall be able to reflect the present audit market concentration ration level more visually. As for the research on audit market, CR index is more scientific and visual, as well as the most common index to assess the audit market concentration ratio level. More, compared to other indexes, CR index is easier to obtain, which can be compared with other foreign relevant indexes when calculating CR index. So this article is based on CR index to analyze the audit market concentration ratio of our nation.

Market concentration ratio (CRn) stands for (property, market share, client quantity and so on) the relevant indexes of top companies, of the percentage shared in the whole industry, the computational formula is as below:

$$
C R n=\sum_{\mathrm{i}=1}^{\mathrm{n}} \frac{X_{\mathrm{i}}}{X} \times 100
$$

In the formula, CRn stands for the market concentration ratio of the top companies in specific industry calculated according to the fixed index $\mathrm{X} . \frac{X_{\mathrm{i}}}{X}$ stands for the market shares of the top companies under the fixed index. In this article CRn stands for the market share of the top firms of the relevant values in audit market. Then the article would take the 2015 - 2017 three years data as the researching sample, to analyze the concentration ratio situation of the audit market in our nation from the aspect of client property amount and client quantity.

\section{Investigation on Audit Market Concentration Ratio: based on Client Property Amount}

In the market, auditing firms' scale reflects their personal ability on a certain extend. So they can attract a mass of client groups by their high professional and better reputation, these client groups are usually with solid property. In this way we can realize that the audit market concentration ratio and 
client property amount is closely related. According to this, client property amount has became an index for us to investigate the audit market concentration ratio of our nation. Please refer to sheet 1 and fig 1 for the investigation result.

Table 1 Audit market concentration ratio based on client property amount

\begin{tabular}{|c|c|c|}
\hline Year & CR4 & CR8 \\
\hline 2015 & $28.73 \%$ & $40.87 \%$ \\
\hline 2016 & $29.10 \%$ & $41.12 \%$ \\
\hline 2017 & $31.63 \%$ & $45.02 \%$ \\
\hline
\end{tabular}

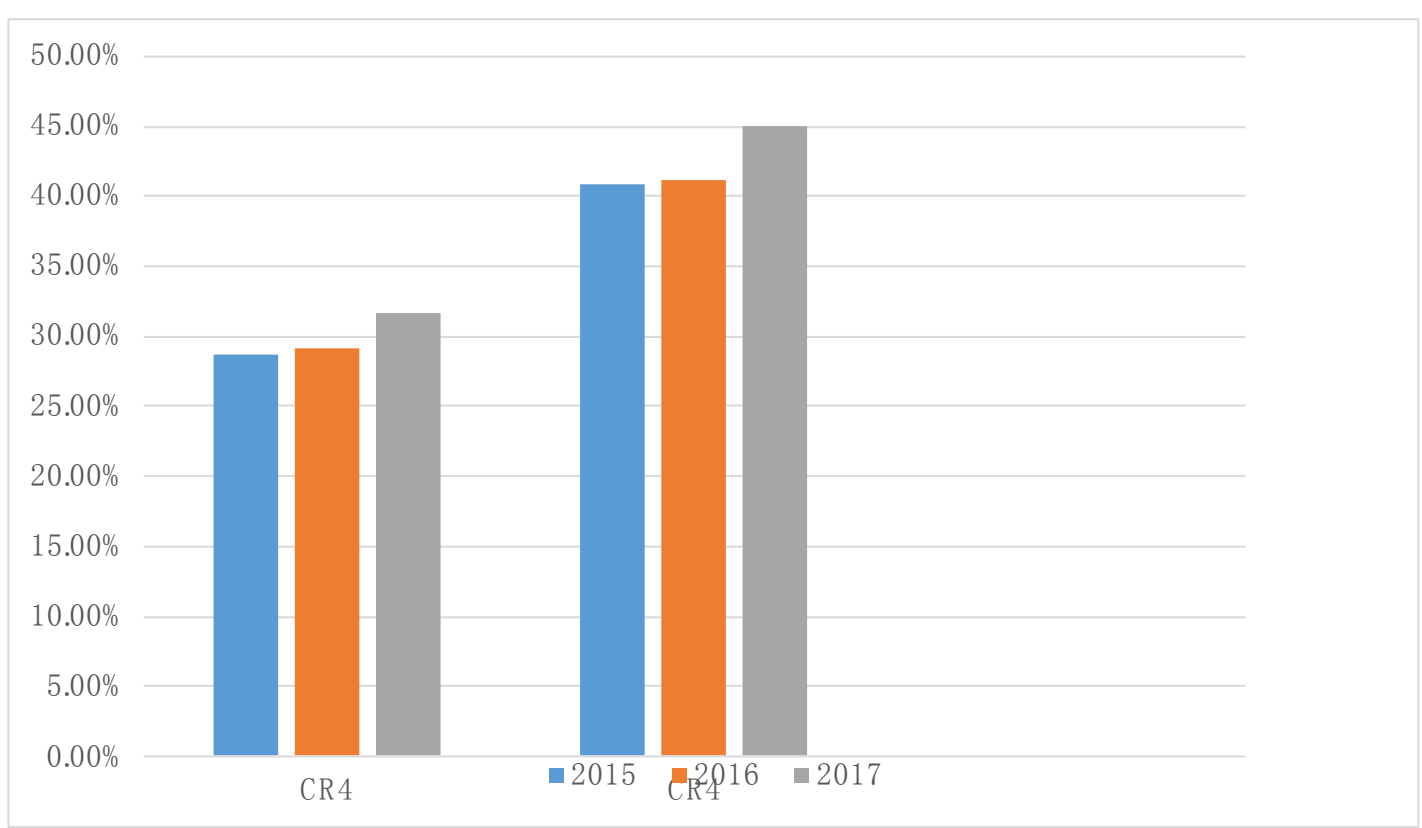

Fig. 1 Audit market concentration ratio based on client property amount / histogram

According to the investigation result of audit market concentration ratio based on client property amount, it reflects that between 2015 and 2017, the audit market concentration ratio of our nation was quite low, all auditing firms were quite dispersive, CR4 was obviously less than 40\%, CR8 was quite distant from $80 \%$. To vertically compare the amplification of the passed 3 years, it can be realized that, as time went by, the market share of the top 4 and top 8 auditing institutions were increasing, while the amplification was not obvious.

\section{Investigation on Audit Market Concentration Ratio: based on Client Quantity}

In the market, the auditing firms which share a mass of market share would usually have better reputation, so it is possible to attract more new clients by improving personal reputation. In this way the audit market concentration ratio and client quantity is highly related. Thus this article takes the client quantity of auditing firms to measure the audit market concentration ratio of our nation of 2015 - 2017, please refer to sheet 2 for the investigation result

Table 2 The investigation on audit market concentration ratio based on client quantity

\begin{tabular}{|c|c|c|}
\hline Year & CR4 & CR8 \\
\hline 2015 & $45.39 \%$ & $62.92 \%$ \\
\hline 2016 & $46.67 \%$ & $63.56 \%$ \\
\hline 2017 & $47.96 \%$ & $63.79 \%$ \\
\hline
\end{tabular}




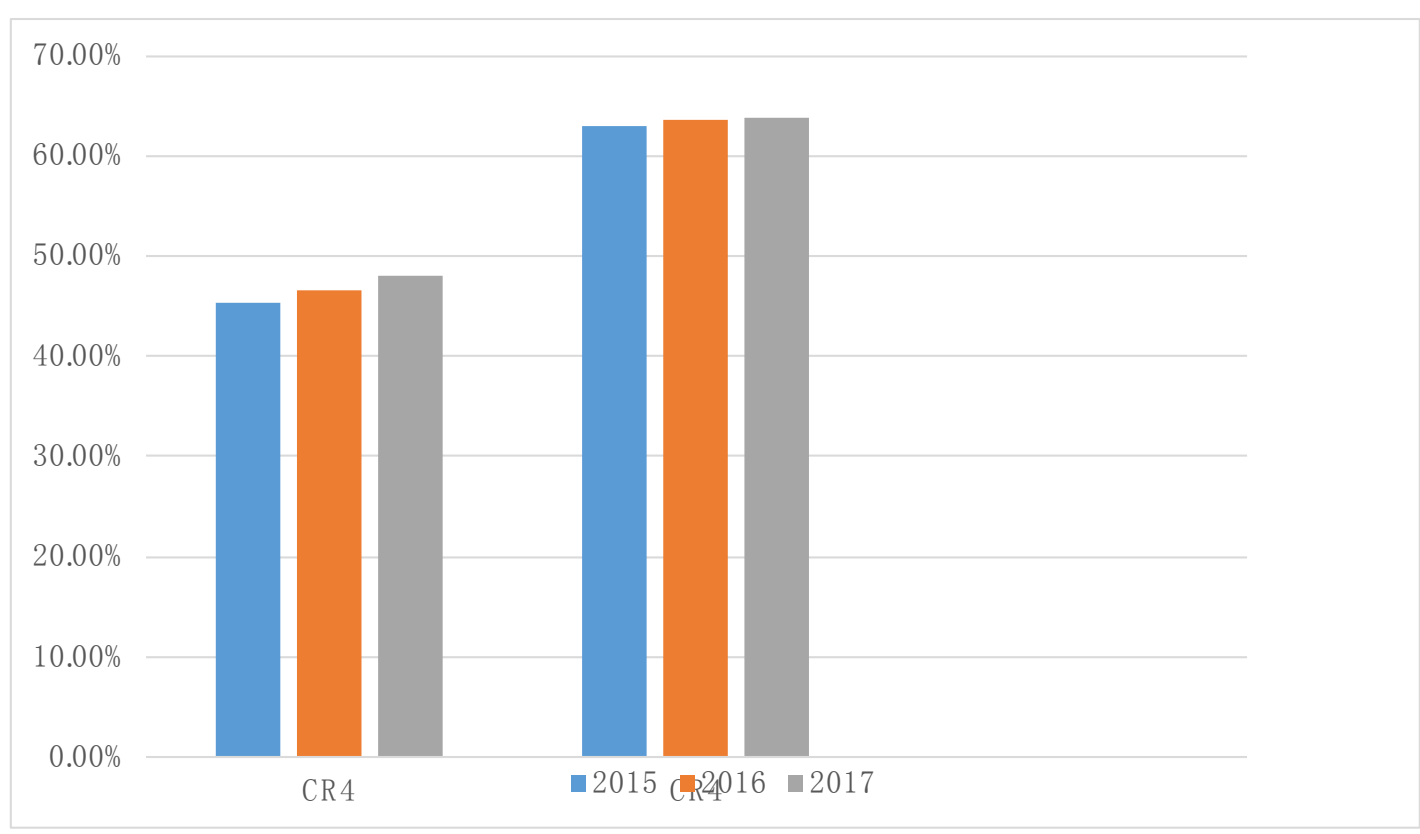

Fig .2 The investigation on audit market concentration ratio based on client quantity / histogram

Indicated from the investigation on audit market concentration ratio based on client quantity that, the top 4 auditing firms of the market share had reached above 40\%, while the top 8 auditing firms did not achieve 80\%. More ever, the market share among 2015 - 2017 was increased by a little, this conforms to the investigation conclusion based on client capital amount.

\section{Analysis on the Audit Market Concentration Ratio of our Nation}

By analyzing the audit market concentration ratio of our nation from the view of client property amount and client quantity, it can be realized that, the domestic large-scaled audit institutions market share is very steady. On a certain extend it reflects that, the top rank firms have maintained a quite steady client quantity and the growth rate on client property amount, so the personal operating receipt growth rate and market share is also steady. However, from the view of client quantity and client property amount, at present the audit market of our nation is quite low on CR4 and CR8. In can be concluded from industrial organizational theory that, the audit market of our nation is appearing with a trends of low concentration and monopolistic competition at present.

\section{Researching Conclusion and Countermeasures}

This article processed investigation and analysis on the audit market concentration ratio of our nation from the view of client quantity and client property amount, and reached the conclusion that: at present, the audit market concentration ratio of our nation is appearing with a trends of low concentration and monopolistic competition. At present in securities market there are over 40 auditing firms from our country to attend the auditing. Combining with the investigation and analysis on audit market concentration ratio of the article, it can be realized that, the individual scale of the auditing firms in our nation still have some distance to the requires of scale economy. According to the western experience, this would obviously have negative influence on auditing quality. According to the current situation and actual national conditional of the audit market in our nation, the article thinks during the process of optimizing audit market result, the market and government shall play a very important role. Which is to concentrate on constructing huge scaled auditing firms, and form up the scale economy and improve auditing quality.

In details, the security auditing market mainly influences the subject behavior of auditing firms by the following aspects: (1) the changes on requirement for market access and exit mechanism, which 
requires the auditing firms to adjust according to this, in this way auditing firms would have mergers to satisfy the standard. (2) The supervision level of security auditing market would have influence on the innovation mechanism and revolution direction of firms. (3) Starting from the current industrial organizational theory, the expanding of requires on security auditing requires would aggravate the competitive degree of auditing market, and to encourage auditing firms to change their behavioral motive, and actively seek for scale economy and scope economy by merger, and reinforce personal competitiveness. In this way, according to the actual national condition of our nation, the market structure of audit industry shall find a balance between market competition and governmental intervention. On the other hand, the government shall adjust the market rules according to market structure, to issue corresponding policies to encouraged the satisfied auditing institutions of becoming larger and stronger. Also the government shall strengthen the macro supervision, to try to build up a fair, transparent, good reputation auditing market environment. Meanwhile, the firms themselves shall also tightly seize the opportunity in developing market, to adjust the developing direction personally by “invisible hand”, to achieve the scale economy and improve auditing quality.

\section{References}

[1] Zeff SA, Fossum RL. An analysis of large audit clients[J]. The Accounting Review, 1967, 42 (2): 298-320.

[2] Schiff A, Fried HD. Large companies and the big eight: an overview[J]. Abacus, 1976, 12 (2): 116-124.

[3] Danos P, Eichenseher JW. Long-term trends toward seller concentration in the US audit market[J]. Accounting Review, 1986: 633-650.

[4] Dye RA. Auditing standards, legal liability, and auditor wealth[J]. Journal of Political Economy, 1993, 101 (5): 887-914.

[5] DeAngelo LE. Auditor size and audit quality[J]. Journal of accounting and economics, 1981, 3 (3): 183-199.

[6] Choi J-H, Kim C, Kim J-B, et al. Audit office size, audit quality, and audit pricing[J]. Auditing: A Journal of practice \& theory, 2010, 29 (1): 73-97.

[7] Ding R, Jia Y. Auditor mergers, audit quality and audit fees: Evidence from the PricewaterhouseCoopers merger in the UK[J]. Journal of Accounting and Public Policy, 2012, 31 (1): 69-85. 